\title{
Agricultural Loans, as Catalyst for Food Production in Nigeria: The Problems and Prospects
}

\author{
Ojiegbe Joe Ngozi Ph.D ${ }^{1} \&$ Duruechi Anthony H. ${ }^{1}$ \\ ${ }^{1}$ Department of Banking \& Finance, Imo State University, Owerri, Nigeria \\ Correspondence: Duruechi Anthony H., Department of Banking \& Finance, Imo State University, Owerri, Nigeria. \\ Tel: 234-80-6089-7635.
}

Received: October 31, 2015

Accepted: November 20, 2015

Online Published: December 13, 2015

doi:10.5430/rwe.v6n4p53

URL: http://dx.doi.org/10.5430/rwe.v6n4p53

\begin{abstract}
The global demand for food is on the increase as a result of the growing world population. Many governments of the developing economy, Nigeria being one of them, have recognized these facts and have initiated various policies to ensure that loans are granted to agriculture. In recognition of the vital role agriculture plays in food production, the Nigerian government has established specialized banks and agricultural funds to carter for the financial needs of Nigeria farmers. However, the problem is the method of food production. Mechanized farming which ensures large-scale production is capital intensive, considering the assertions that agricultural loan is a sine qua non to food production. Therefore, this paper evaluates the impact of these agricultural loans on food production, the problems and prospects. Data for the study were sourced through secondary means and hypotheses formulated in order to attain the objective of the research. The data were analysed with SPSS (multiple regression) and formulated hypotheses tested with F-ratio and student t-test. Findings revealed that agricultural loans have significant and positive impact on food production in Nigeria. Hence, there is need to increase and sustain the amount of credits disbursed to the sector if the rate of food production is to meet with the pace at which the population is growing.
\end{abstract}

Keywords: food production, agricultural loans, catalyst, prospects in Nigeria

\section{Introduction}

The history of lending to the agricultural sector in Nigeria dates back to the $50 \mathrm{~s}$ and $60 \mathrm{~s}$ when banks played significant role in the activities of the marketing board. As agents of farmers, the banks making credits available to them, as well as the licensed buying agents. They provided short and medium term credits to the farmers, in order to enable them embark on their agricultural projects, of which food production was one of them. More so as agriculture remains the mainstays of the economy, as it is the largest sector in terms of its share in employment (Philip, Nkonya, Pander and Oni 2009).

On the role which agricultural credits played in food production in advanced countries, especially United State of America, Aaron et al (1973) observed that borrowing was used more extensively in the United States of America to gain control of additional resources. Money lenders played important roles in enabling the farming sector utilize more borrowed capital. Bauman (1966), in his contribution, noted that the agricultural credits to primary producers (food production being one of them) was not the function of Deposit Money Banks in Nigeria. According to him, at various times and in various ways, attempts were made to provide some credits to agriculture and the results were usually negative. Currently very little Deposit Money Banks' credit is available for primary productions except for large estates. He said that Barclays Bank (now Union Bank) which was the major source of credit then, was actively exploring new ways to broaden their agricultural activities.

Today, the involvement of banks in agricultural financing takes various forms. In addition to funding licensed buying agents, the banks fund project by corporate bodies, co-operative societies and individuals as well as groups of farmers. The banks lend to States and agricultural co-peratives who further lend to farmers. There is no doubt that the major force behind their involvement in food production in an appreciable level is the "big stroke" of the Central Banks Credit Guideline.

In evaluating the role banks play in financing agriculture for food production, the increased attention which the Government and Central Bank have been giving to the sector since 1977 should be recognized. Agriculture has been 
placed in the preferred sector of Central Bank's Credit Guidelines. Furthermore, agricultural production has come into greater favour from a lowly proportion of $4 \%$ in 1974 to $10 \%$ in 1984 and $18 \%$ in 1994 . With these it is agreeable that agriculture has assumed its rightful place in the eyes of the authorities. In order to ensure banks' compliance with these provisions, stiff penalties were prescribed in the credit guidelines. In particular, where a bank's total monthly loan and advances to agriculture fall short of the guideline stipulation of minimum ratio, such bank is required to deposit the amount of the shortfall with the Central Bank of Nigeria, (CBN 2005). Though majority of the banks were unable to attain the targets in the early years of the guideline, there have been substantial achievements in the later years.

The Central Bank's first involvement in agricultural financing started as far back as 1962 when refinancing facilities was extended to the consortium of Deposit Money Banks for the purpose of discounting the ninety days bill of exchange drawn by the Nigeria Produce Marketing Limited (Asabia 1990). The Central Bank Credit Guidelines on sectoral allocation stipulates what percentage of loans and advances that should be given to the agricultural sector by banks. In 1972 when the scheme was introduced, forty percent $(40 \%)$ of total loans were allocated to agriculture. Banks became more directly involved in agricultural lending in 1970 and this lending has been a major contributory factor to the increase in agricultural production. According to Obansa and Maduekwe (2013), agricultural loan has the potential to stimulate food security.

The poor participation of Deposit Money Banks in agricultural financing induced the Central Bank to introduce the sectoral allocation system, which many banks hardly complied with as expected by the Central Bank. This mandatory bank credit allocation was abolished in October 1996 following the liberalization of the financial sector. Banks were rather enjoined to voluntarily provide adequate credit to all sectors of the economy to ensure growth and that rural borrowers were not left out. (CBN, 2003) According to Eko (2014), this directive has prompted some banks to maintain certain level of association with farmers.

Agriculture which consists, among others, the growing of crops and rearing of animals can easily be said to be man's oldest and most important occupation. From the beginning of creation man needed food for his- sustenance. This need has never been adequately met and when it is met it has always been for a while. Thus man has been faced with periods of famine, which has been of great concern to man in all generations since, this, distorts all other aspects of life. In order to deal with the problems of food supply, individuals, organizations, communities and governments should invest huge amount of economic resources to the agricultural sector. In Nigeria, the agricultural sector is adjudged not to have performed well as the country is still importing most of its consumables. The nation has been experiencing persistent and inadequate supply of food items and other agricultural products, hence, the reliance on importation.

In the opinion of Bango (2001) the poor performance of agricultural sector in Nigerian's economy with its resultant food shortages and high food prices over the years has been aptly attributed to inadequate capital to finance agricultural investments. The agricultural sector of the Nigerian economy has continued to attract relatively less than proportionate amount of fund from the government. Major operators in the economy prefer to allocate their funds to other competitive sectors of the economy vis-a-vis commerce and industries where the prospects for quick and fast gains exist. In identifying the factors that make agricultural products less competitive and attractive than projects implemented in the commercial and industrial sector Ajakaiye (1993) included factors such as high risks occasioned by the vagaries of the weather, low rate of returns and long gestation periods associated with agricultural products. He further stated that in order to stem the trend in the agricultural sector of the economy and improve on the domestic supply of food and other agricultural products, the Federal government of Nigeria has made series of policies, and issued directives to organized sectors of the economy persuading them to invest significantly in the agricultural sector. Inspite of the achievements made in agricultural financing, critics of the economy argue that no significant improvements have been made. It is, therefore, in the light of the above that this paper intends to probe into the role agricultural loans play in food production.

The problems as observed by the writer is that Deposit Money Banks are reluctant to comply with the Central Banks of Nigeria Credit Guidelines as it concerns agriculture. The question is, has agricultural financing improved agricultural performance (food production) in Nigeria? The paper highlights the constraints that militate against the participation of banks in agricultural lending as it tries to ascertain whether agricultural financing has improved food production.

Banks in the modern economies form important segment of financial system. They are the most significant intermediaries between fund owners and fund seekers. Banks make funds available to investors. Granting of loan to investors generates the highest return to banks. Thus, all banks grant loans to their customers. Banks, especially 
Deposit Money Banks, are very skeptical about funding agricultural project. Deposit Money Banks' participation in agricultural lending was made possible by the Central Bank directives which stipulated that all commercial banks in Nigeria should channel a minimum of $15 \%$ of their total loans and advances to agriculture (Ajakaiyi, 1993). With the current wave of development in agriculture, many farmers have been attracted to different types of innovations, such as crop rotation, improved seedlings and sophisticated farm implements.

Deposit Money Banks' lendings to the agricultural sectors have been on the increase since 1996 Lemo, (2005) observed that their services were at the doorsteps of the rural dwellers. The inputs of agricultural funding have gone a long way, especially when the Federal Government set up the Nigeria Agricultural and Cooperative Bank now Nigeria Agricultural Cooperative and Rural Development Bank. Credit is a vehicle for agricultural development and it is necessary, if agriculture is to derive the benefits of improved technology which ensures improved food production.

The need for financial aid to agriculture, in form of credit delivery stemmed from the following factors.

1. The seasonality of farming which results in farmers' income being unstable and seasonal

2. The need to meet with labour expenses

3. The provision of adequate storage arrangement which would enable the farmer hold stock till favourable prices prevail in the market

4. The need to service capital equipment and purchase inputs.

5. The need to meet with their financial commitments outside the farm.

The various uses into which agricultural financing is put shows the need for agricultural credit institutions to overcome what ever problem they have so as to mobilize all their financial resources for agricultural development in particular and economic development in general. Olayide and Ogwuma (1985) believed that the use of farm credit as a necessary input for the structural transformation and expansion of rural agriculture production could not be over emphasized. They also agreed that the bulk of farm credit in Nigeria came from private sources; which were largely inefficient. They went further to say that for efficiency, credit should be institutionalized and backed with adequate funding, proper supervision and timeliness of operations.

It seems that the basic reason for government concern over the dwindling condition of the economy is the recognition of the important ways in which agricultural output and productivity ought to contribute to the overall economic growth. However adequately financed agricultural sector would therefore:

a. Ensure that food supplies are adequate in quantity and quality to keep pace with the population growth and urbanization.

b. Expand the production of export commodities with a view to increasing and diversifying the country's foreign exchange earnings

c. Increase significantly the production of agricultural raw materials for export and domestic manufacturing activities especially in the agro-based industries.

d. Create rural development opportunities to absorb more of the increasing labour force and minimize the tendency for inadequate and inefficient use of human resources in rural areas.

\subsection{Research Questions}

In order to achieve the objective of this research work, the following questions were raised:

1. To what extent have agricultural loans impacted on the level of food production in Nigeria?

2. What direction and impact do loans on crop production have on agricultural output in Nigeria?

3. How has the amount of loans advanced on livestock affected the level of food production in Nigeria?

4. In what direction have loans on forestry impacted on food production in Nigeria?

5. What impact do loans on fishery have on food production in Nigeria?

\subsection{Research Hypotheses}

Based on the questions raised, the following hypotheses were formulated:

$\mathrm{H}_{\mathrm{ol}}$ : Agricultural loans do not have significant impact on food production in Nigeria.

$\mathrm{H}_{02}$ : Loans on crops production do not impact positively on agricultural output in Nigeria. 
$\mathrm{H}_{03}$ : Loans for livestocks have not impacted positively on food production on Nigeria.

$\mathrm{H}_{04}$ : Loans on Forestry have no significant positive effect on agricultural output in Nigeria.

$\mathrm{H}_{\mathrm{o} 5}$ : The amounts of loans advanced on fishery do not significantly correlate with the amount of agricultural produce in Nigeria.

\section{Problems of Agricultural Financing}

The inherent problems of financing agriculture by banks have been in existence for decades. In Nigeria the introduction of Structural Adjustment Programme, the deregulation of interest rate and market liberalization scared banks away from financing agriculture (Odu, 2007). The constraint in financing agriculture by banks could be both internally and externally. The internal constraints arose as a result of the bank's nature of operations, the need for security, and shortage of qualified personnel. Deposit Money Banks are profit-oriented and therefore prefer to lend for a short period of time because of the term nature of their deposits. Banks operate with deposit funds which are borrowed from their customers. Therefore the banks require easily marketable securities or collaterals which they can sell easily in order to recover their principal amount and interest. Bank loans are easily not attracked because the securities or collaterals needed for such loans are beyond the reach of many farmers.

The external constraints, according to Chidebelu (2004), were made up of certain government policies, deficient infrastructures, and farmers themselves. These government policies included the abrogation of concessionary interest rate policy, closure of unprofitable rural branches of these banks, withdrawal of government and parastatal accounts from Deposit Money Banks and the closure of some distressed banks. These events affected the banks' ability in participating effectively in agricultural lending. On the part of the farmers, they had nothing acceptable to offer as security. The land or building on which they operate probably belong to the community or rented from landlords. A greater percentage of them were illiterates and ignorant of the schemes and efforts towards agricultural development. The farmers lacked courage to demand for credits as well as the desire to walk to the bank to request for assistance of any sort. The other problem caused by the farmers was loan diversion as they used this loans, when given, for different purposes outside agricultural projects. It is on record that many farmers who had the opportunity of securing loans meant for agriculture used them in building mansions and buying vehicles during the civilian/military administration. Some used theirs in marrying more wives and taking chieftaincy titles while some used theirs to send their wards outside the country, believing it to be their own share of the "national cake". Another problem was that of loan default by farmers, which is endemic in Nigeria and in most developing countries. The Food and Agriculture Organization in 1994 observed that the inability of farmers to repay loan was traceable to the imperfection of the credit delivery system and a host of institutional factors. They stated that factors like poor management skill, poor sale of their products, unsuitable technology, natural disaster (such as draughts) pests and unnecessary rapid inflexible repayment arrangement were responsible for loan default.

\section{Prospects of Agricultural Financing}

The key objective of agricultural financing is to provide the farmers with funds and financial services with which to multiply their earnings and build a more prosperous future. To achieve this, efforts must be made to overcome the several constraints militating against the farmers' ability to enjoy financial assistance.

In the light of the above, credit institutions should be involved in the following,

1. Mapping out special flexible lending policies that should benefit both the lender and the borrower,

2. A proper appraisal of the credit needs of the farmers so as to ensure repayment, and

3. Providing the farmers with timely credit and inputs,

These can be achieved through manpower development, employing lending procedures and decentralizing their operational authorities. There should be direct contact between credit institutions and other government' agencies supplying other inputs and the farmers themselves, with the objective of improving mutual understanding between them.

Banks, like any other business organizations, are established to run as profit entities. As such, it is proper that banks will like to invest their capital in areas where the opportunities for profitability are highest. In Nigeria it seems that agriculture is not a high profit yielding business when compared with trade, commerce and industry, hence it does not easily attract funds from the financial market. For these reasons, the following measures should be put in place to make agriculture feasible for bank lending. 
a. Agriculture must be made to become a profitable sector of the economy on business terms. To achieve this, government should guarantee prices of farm produce by buying surplus output in time of good harvest. Farmers should be assisted by providing preservatives and storage facilities, irrigation dams, improved seedlings, pest control facilities and international market for their cash crops; exactly what President Obasanjo's regime did with cassava production.

b. There should be consistency in government policies. Government should monitor the implementation of their polices by banks to ensure compliance.

c. Cost of obtaining these loans should be made very minimal since agriculture is not a money spinner, but still very important to all sectors of the economy and as such cannot be neglected. Where cost of obtaining this capital is made low for agricultural project, farmers will avail themselves of the opportunities and thereby increase their scale of production and food will be in abundance.

d. To ensure that farmers do not default on these loans, there should be an effective monitoring of the loan immediately after disbursement. This is to ensure that every bit of the loan is invested on what it is intended. It will prevent the possibility of fake farmers obtaining loans and diverting them to other uses thereby building up the banks confidence in granting loans to agriculture.

\section{Acquisition of Agricultural Credit by Farmers}

The role of agricultural credits in developed and developing economy cannot be over emphasized. Credits make it possible for farmers to take advantage of new machines, good seedlings, fertilizer, liver stock and labour all of which enable the farmers organize and operate their farms on more profitable bases. In Nigeria, according to Miller (2005), agricultural credits to primary producers was not the function of Deposit Money Banks. He went further to state that at various times and in various ways, attempts were made to provide some credits to agriculture and the results were usually negative. The farmers themselves had their own portion of blame. It is revealed that only $12 \%$ to $15 \%$ of the credits extended to farmers were used in primary production while the balance was consumed (CBN 2005).

Federal government in its 1991 budget directed that in granting agricultural loans, priority should be given to areas with high agricultural production potentials as a way of supporting the national food self-reliant effort. Government by this directive acknowledged the pr-eminent position of agriculture in the performance of the national economy, its potential for savings on food expenditure in scarce foreign exchange and a source of employment for the unemployed. Commenting on agricultural credits in less developed countries, Belshaw (1978) observed that the problem of underdeveloped countries is how to devise institutional agencies and procedure both publicly and privately, which will promote savings and the smooth flow of funds, to where they can be used, mostly for the production of goods as cheaply and efficiently as possible, under condition suited for the needs of agriculture.

Modernizing agriculture requires coordination of a number of activities, such as extension services, proper estimation of credit needs, timely and adequate supply of inputs, repayment arrangement suited to the ability and convenience of the farmers, effective machinery for debt recovery. In Nigeria, poor road network makes it a difficult task to keep in touch with numerous borrowers who are mainly rural dwellers many of whom may have little appreciation of credit principle. This lack of appreciation of the credit principles causes the diversion of loan and non-repayment when it falls due.

\section{Methodology}

For the purpose of achieving the objectives of this work, data were basically drawn from secondary sources. The said data cover the entire Nigerian economy $(1992$ - 2012) and were collected from Central Bank of Nigeria Statistical Bulletin of 2012 and National Bureau of Statistics (NBS). They (data) were analysed with the aid of multiple regression through the use of SPSS (Statistical Package for Social Sciences). The hypotheses of the work were tested with $\mathrm{F}$ - test and student $\mathrm{t}$ - test. The techniques or model for estimating the parameters of the equation were given as

Where

$$
\begin{gathered}
\mathrm{Y}=\mathrm{a}_{0 \mathrm{t}}+\mathrm{a}_{1} \mathrm{X}_{1 \mathrm{t}}+\mathrm{a}_{2} \mathrm{X}_{2 \mathrm{t}}-----\mathrm{an}_{\mathrm{nt}}+\mu \\
\mathrm{AGDP}=\hat{\mathrm{a}}_{0}+\hat{\mathrm{a}}_{1} \mathrm{CPR}_{\mathrm{t}}+\hat{a}_{2} \mathrm{LTK}_{\mathrm{t}}+\hat{\mathrm{a}}_{3} \mathrm{FORS}_{\mathrm{t}}+\hat{\mathrm{a}}_{4} \mathrm{FISH}_{\mathrm{t}}
\end{gathered}
$$

AGDP (y) = Agricultural Gross Domestic Product (Output)

CPR $\left(\mathrm{x}_{1}\right)=$ Total Loans on Crop Production (Food + Cash Crops)

$\operatorname{LSTK}\left(\mathrm{x}_{2}\right)=$ Total Loans on Livestocks 
FORS $\left(\mathrm{x}_{3}\right)=$ Total loans on Forestry (others)

FISH $\left(\mathrm{x}_{4}\right)=$ Total Loans on Fishery.

$\mathrm{U}=$ Stochastic Variable(s) or error term

Other econometric analysis carried out include

Autocorrelation: This was tested using Durbin - Watson statistic which was used to detect whether error term for one observation is not influenced by the error term from the regression analysis.

According to Durbin and Watson (1971) if Durbin-Watson statistic is less than 2 there is evidence of positive serial correlation. If Durbin-Watson is less than I, there may be cause for alarm. Small values indicate successive error terms are on average, close to one another or positively correlated.

Coefficient of Determination $\left(\mathbf{R}^{2}\right)$ : It examined the proportion of variation(s) in the dependent variable (Y) explained by changes in the independent variables $\left(\mathrm{X}_{\mathrm{s}}\right)$.

\subsection{Presentation of Data}

\begin{tabular}{|c|c|c|c|c|c|c|}
\hline \multicolumn{7}{|c|}{ SIR T.sav } \\
\hline & YEAR & AGDP & CPR & LSTK & FORS & FISH \\
\hline 1 & 1992 & 132699.20 & 82683.90 & 6056.10 & 3213.10 & 1038.70 \\
\hline 2 & 1993 & 135185.18 & 72636.90 & 5505.80 & 2703.10 & 428.00 \\
\hline 3 & 1994 & 138753.57 & 90166.80 & 10527.90 & 3768.30 & 2438.00 \\
\hline 4 & 1995 & 143706.30 & 134566.90 & 18048.50 & 11517.70 & 1512.00 \\
\hline 5 & 1996 & 149512.02 & 187012.30 & 28216.90 & 10290.30 & 2145.00 \\
\hline 6 & 1997 & 155934.80 & 201247.10 & 23404.70 & 13822.00 & 3554.50 \\
\hline 7 & 1998 & 162248.76 & 182961.90 & 22587.10 & 10283.50 & 3456.00 \\
\hline 8 & 1999 & 170813.88 & 208978.00 & 11952.00 & 14524.00 & 6180.00 \\
\hline 9 & 2000 & 175876.60 & 308605.00 & 27307.00 & 24638.00 & 899.00 \\
\hline 10 & 2001 & 182660.00 & 622694.70 & 60415.70 & 29692.80 & 15742.20 \\
\hline 11 & 2002 & 190369.10 & 938949.10 & 64449.60 & 18214.30 & 12069.30 \\
\hline 12 & 2003 & 203012.61 & 1026155.60 & 100486.40 & 2990.00 & 13050.00 \\
\hline 13 & 2004 & 216208.46 & 182582.70 & 190304.00 & 49098.00 & 18240.00 \\
\hline 14 & 2005 & 231463.61 & 8321931.70 & 844882.80 & 49635.00 & 262195.00 \\
\hline 15 & 2006 & 248598.96 & 3770549.30 & 368151.00 & 8330.00 & 114400.00 \\
\hline 16 & 2007 & 266477.18 & 3913774.30 & 353487.30 & 17510.00 & 140690.00 \\
\hline 17 & 2008 & 283175.43 & 4965964.70 & 1108432.80 & 54880.50 & 368630.00 \\
\hline 18 & 2009 & 299823.86 & 5794654.00 & 1725801.30 & 86559.30 & 708621.20 \\
\hline 19 & 2010 & 317281.65 & 5294716.10 & 1305432.50 & 716510.00 & 461128.00 \\
\hline 20 & 2011 & 335180.07 & 6766687.10 & 1878263.40 & 443645.30 & 589667.50 \\
\hline 21 & 2012 & 348490.80 & 6388007.00 & 1878043.00 & 107355.50 & 378311.90 \\
\hline
\end{tabular}

\section{Data Analysis and Discussion of Results}

Regression

C: Documents and Settings $\backslash$ userlMy Documents /SIR Tsav

\section{Variables Entered/Removed}

\begin{tabular}{|c|c|c|c|}
\hline Model & Variables Entered & Variables Removed & Method \\
\hline 1 & FISH, FORS, CPR, LSTK ${ }^{3}$ & & Enter \\
\hline
\end{tabular}

a. All requested variables entered. 
Model Summary $^{5}$

\begin{tabular}{llclll}
\hline & & & & \multicolumn{2}{l}{ Std. Error of the } \\
Model & $\mathrm{R}$ & R Square & Adjusted R Square & Estimate & Durbin-Watson \\
\hline 1 & $.934 \mathrm{a}$ & .873 & .841 & 27939.51316 & 1.644
\end{tabular}

a. Predictors: (Constant), FISH, FORS, CPR, LSTK

b. Dependent Variable: AGDP

ANOVA $^{b}$

\begin{tabular}{lllllll}
\hline \multicolumn{1}{c}{ Model } & Sum of Squares & df & Mean Square & F & Siq. \\
\hline 1 & Regression & $8.597 \mathrm{E} 10$ & 4 & $2.149 \mathrm{E} 10$ & 27.534 & $.000^{\mathrm{a}}$ \\
& Residual & $1.249 \mathrm{E} 10$ & 16 & $7.806 \mathrm{E} 8$ & & \\
& Total & $9.846 \mathrm{E} 10$ & 20 & & & \\
\hline
\end{tabular}

a. Predictors: (Constant), FISH, FORS, CPR, LSTK

b. Dependent Variable: AGDP

\section{Coefficients $^{\mathrm{a}}$}

\begin{tabular}{|c|c|c|c|c|c|c|}
\hline \multirow[b]{2}{*}{ Model } & & \multicolumn{2}{|c|}{ Un standardized Coefficients } & \multicolumn{2}{|l|}{$\begin{array}{l}\text { Standardized } \\
\text { Coefficients }\end{array}$} & \multirow[b]{2}{*}{ Siq. } \\
\hline & & $\bar{B}$ & Std. Error & Beta & $\mathrm{t}$ & \\
\hline \multirow[t]{5}{*}{1} & (Constant) & 163268.715 & 8088.143 & & 20.186 & .000 \\
\hline & CPR & .007 & .005 & .298 & 3.567 & .137 \\
\hline & LSTK & .086 & .036 & .833 & 2.908 & .028 \\
\hline & FORS & .046 & .046 & .115 & 4.997 & .334 \\
\hline & FISH & .081 & .102 & -.256 & 3.795 & .438 \\
\hline
\end{tabular}

a. Dependent Variable: AGDP

\section{Coefficients $^{\mathrm{a}}$}

\begin{tabular}{llll}
\hline & & Collinearity Statistics & \\
\cline { 3 - 4 } Model & & Tolerance & VI F \\
\hline 1 & CPR & .219 & 4.557 \\
& LSTK & .066 & 15.115 \\
& FORS & .597 & 1.676 \\
& FISH & .076 & 13.105 \\
\hline
\end{tabular}

a. Dependent Variable: AGDP

\section{Collinearity Diagnostic ${ }^{a}$}

\begin{tabular}{lcll}
\hline & & & \\
\cline { 3 - 4 } Model & Dimension & Eiaenvalue & Condition Index \\
\hline 1 & 1 & 3.868 & 1.000 \\
& 2 & .605 & 2.529 \\
& 3 & .411 & 3.067 \\
& 4 & .089 & 6.575 \\
& 5 & .026 & 12.188 \\
\hline
\end{tabular}

a. Dependent Variable: AGDP 


\section{Collinearity Diagnostic ${ }^{\mathrm{a}}$}

\begin{tabular}{lllllll}
\hline \multirow{2}{*}{ Model } & Dimension & \multicolumn{5}{l}{ Variance Proportions } \\
\cline { 2 - 6 } & (Constant) & CPR & LSTK & FORS & FISH \\
\hline 1 & 1 & .02 & .01 & .00 & .02 & .00 \\
& 2 & .66 & .00 & .00 & .20 & .00 \\
& 3 & .20 & .04 & .01 & .69 & .01 \\
& 4 & .12 & .90 & .05 & .09 & .14 \\
& 5 & .00 & .06 & .94 & .00 & .85 \\
\hline
\end{tabular}

a. Dependent Variable: AGDP

Residuals Statistics ${ }^{\mathrm{a}}$

\begin{tabular}{llllll}
\hline & Minimum & Maximum & Mean & Std. Deviation & $\mathrm{N}$ \\
\hline Predicted Value & 164374.2500 & 348269.7500 & 213689.1448 & 65563.86978 & 21 \\
Residual & -47597.62891 & 54210.75781 & .00000 & 24989.86028 & 21 \\
Std. Predicted Value & -.752 & 2.053 & .000 & 1.000 & 21 \\
Std. Residual & -1.704 & 1.940 & .000 & .894 & 21 \\
\hline
\end{tabular}

a. Dependent Variable: AGDP

\section{Coefficient of Determination $\left(\mathbf{R}^{2}\right)$}

From the SPSS results, the $\mathrm{R}^{2}$ value $=0.873 \approx 87.3 \%$. This means that the explanatory or independent variables (loans on crops production, livestock, forestry and fishery $-\mathrm{X}_{1}, \mathrm{X}_{2}, \mathrm{X}_{3}$ and $\mathrm{X}_{4}$ ) account for $87.3 \%$ changes in the endogenous or dependent variable (AGDP - Y). The remaining 12.7\% may be due to other factors. This makes the model a good one.

\section{Auto-Correlation}

The Durbin - Watson Statistic value was 1.644. This tends to 2 than zero (0) and simply means that autocorrelation is weak. In other words, there is no significant or strong auto-correlation.

\section{Multicollinearity}

The best test for the multicollineraity is the Condition Index (C.I). From the result presented above the condition Index are all less than 30 .

$$
\begin{aligned}
& \mathrm{X}_{1}(\mathrm{CPR})=2.529 \\
& \mathrm{X}_{2} \text { (LSTK) }=3.067 \\
& \mathrm{X}_{3} \text { (FORS) }=6.575 \\
& \mathrm{X}_{4}(\mathrm{FISH})=12.188
\end{aligned}
$$

These results showed that multicollienrarity was not strong enough destroy to destroy the data presented.

\section{Test of Hypotheses}

\section{JOINT TEST OF SIGNIFICANCE (F-ratio)}

$\mathrm{H}_{\mathrm{ol}}$ : Agricultural loans do not have significant impact on food production in Nigeria.

From the SPSS result

$\mathrm{F}-$ calculated $=27.534$

$\mathrm{F}-$ table, $\mathrm{n}-\mathrm{k}, \mathrm{k}-1$

F0.05, $21-5,5-1$

F0.05, 16, $4=3.01$

Decision: Given that Fc (27.534) > F-table value (3.01), the null hypothesis $\left(\mathrm{H}_{\mathrm{o}}\right)$ was rejected and it is therefore concluded that agricultural loans exert significant impact on food production in Nigeria. 


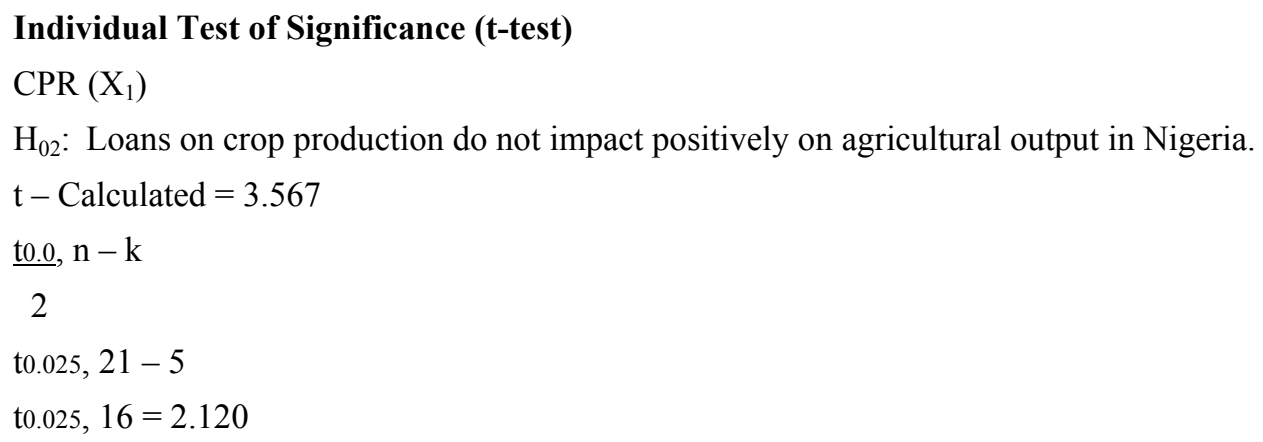

Decision: t-calculated (3.567) $>\mathrm{t}$-table value (2.120). Hence, the $\mathrm{H}_{\mathrm{o}}$ was rejected and it is concluded and it is therefore that loans on crop production impact positively on agricultural output in Nigeria.

LSTK (X2)

Ho3: Loans for livestocks have not impacted positively on food production in Nigeria.

tc $=2.908$

$\mathrm{t}$-table value $=2.120$

Decision: The above depicts that tc (2.908) $>$ t-table value (2.120). Therefore, the reject Ho is rejected and the undivision is mind and loans made in respect of livestocks has impacted positively on food production in Nigeria.

FORS (X3)

Ho4: Loans on forestry have no significant positive effect on agricultural output in Nigeria.

t-calculated $=4.997$

$\mathrm{t}$-table $=2.120$

Decision: Here, tc (4.997) $>$ tt $(2.120)$. Thus, the Ho is rejected and the conclusion is that loans on forestry have significant positive effect on agricultural output in Nigeria.

FISH (X4)

Ho5: The amount of loans advanced on fishery does not significantly correlate with the amount of agricultural produce in Nigeria.

tc $=3.795$

$\mathrm{tt}=2.120$

Decision: $t_{c}(3.795)>t_{t}(2.120)$. Therefore, the null hypothesis $\left(H_{o}\right)$ is rejected and the alternative hypothesis $\left(H_{1}\right)$ is accepted. Conclusively, the amount of loans advanced on fishery significantly correlates with the amount of agricultural produce in Nigeria.

\section{Findings/Economic Evaluation of the Model}

From the above results, the model equation was given as:

$$
\begin{gathered}
\mathrm{AGDP}=\hat{\mathrm{a}}_{0}+\hat{\mathrm{a}}_{1} \mathrm{CPR}_{\mathrm{t}}+\hat{\mathrm{a}}_{2} \mathrm{LSTK}_{\mathrm{t}}+\hat{\mathrm{a}}_{3} \mathrm{FORS}_{\mathrm{t}}+{\widehat{\mathrm{a}_{4}}}_{\mathrm{FISH}_{\mathrm{t}}} \\
\mathrm{AGDP}=163268.7150 .007 \mathrm{CPR}_{\mathrm{t}}+0.086 \mathrm{LSTK}+0.046 \mathrm{FOFS}_{\mathrm{t}}+0.081 \mathrm{FISH}_{\mathrm{t}} .
\end{gathered}
$$

The above analysis depicts that there exists a positive significant relationship between loans advanced for agricultural purposes and the total amount of agricultural output in the economy. Unit(s) increase in the amount of loans advanced for crop production, which comprises cash and food crops cash crops are made up of palm oil, rubber, cocoa, cotton and groundnut whereas food crops include grains, roots and tubers) and this will lead to increase in output by 0.07 units. That of livestock which comprises poultry, cattle, sheep and other livestock forestry and fishery will cause 0.086 units, 0.046 unit and 0.081 unit increases in output (AGDP) respectively. Thus, it means that increases in the amount or values of loans advanced for agricultural produce will yield corresponding increase in the amount of agricultural output. This is in line with a prior expectation.

The work used data obtained from the Central Bank of Nigeria Statistical Bulletin 2012 based on the operations of ACGSF (Agricultural Credit Guarantee Scheme Fund). Loans advanced by latter to various sectors of agriculture 
were evaluated ranging from crop production, livestock, forestry, fishery and agricultural GDP between 1992-2012, as mentioned inter alia.

The trend of the data revealed that within the period under review, loans and advances to the sector has been on the increase, showing much concern for the growth of the sector.

In order to ascertain the level and direction of impact these credits exert on food production or output, the data were subjected to rigorous statistical analysis. The regression analysis revealed that amounts of loans advanced in respect to agriculture hand significant positive impact on food production which was confirmed with the joint test (f-ratio). This was further supported by the regression equation which showed a positive relationship between the loans advanced to each unit or agricultural sector and the output thereof. AGDP $=163268.715+0.007 \mathrm{CPR}_{\mathrm{t}}+0.086 \mathrm{LSTK}_{\mathrm{t}}$ $+0.046 \mathrm{FORS}_{\mathrm{t}}+0.01 \mathrm{FISH}_{\mathrm{t}}$. This can best said to be in line with Nigeria's goal or quest of vision 2020 . No wonder in recent times, the sector has been noted as one of the best after the entertainment industry.

Individual test of significance (t-test) carried out equally confirmed that each component(s) of the sector contributes significantly to food production in Nigeria. Summarily, the following were the results of the research.

1. Agricultural loans have significant impact on food production in Nigeria.

2. Loans on crops production impact positively on food output in Nigeria.

3. Loans extended on livestocks complement food production in Nigeria.

4. Loans on forestry have significant effect on food production.

5. Amounts of loan(s) advanced on fishery significantly correlate with the amount of agricultural (food) output in Nigeria.

\section{Conclusion}

Agriculture offers employment to greater percentage of the population in Nigeria. It plays a central role in the development of the country. Following the oil boom of the seventies, agriculture started to decline which resulted in food shortage that was experienced by the country and is attendant increase in food importation. According to CBN (2005), even toothpicks and bottled water were imported to show affluence. In order to restore the agricultural position in the country, federal government evoked some policy measures like
a. Agricultural credit support scheme,
b. National poverty eradication programme,
c. Agricultural credit guarantee scheme, and
d. New incentives/models for improved lending under the Agricultural Credit Guarantee Scheme Fund.

These policies, if properly implemented, it is believed will boost agriculture and increase food supply. The purposes of the policies are to develop agricultural sector of the Nigeria economy, by providing facilities to farmers to ensure reduction in the prices of agricultural product especially food items, which will eventually lead to reduction in inflation rate, generate surplus for export, diversification of revenue base and increased foreign exchange earnings for Nigeria.

Of all these policy measures, Agricultural Credit Guarantee Scheme is run by the federal government to ensure that finance is made available to agriculture thereby boosting food production. This Scheme provides guarantee to banks that lend to agriculture. This was done with the view to encourage banks to make advances to the agricultural sub-sector of the economy. According to CBN (2005) small farmers expected to benefit immensely from the scheme especially with the introduction of the Trust Fund Model. Under this Trust Fund Model, oil companies, state and local governments and non-governmental organization are to place fund in trust with the lending bankers to augment the savings of the farmers. This added coverage gives further encouragement to the banks to give loans to small farmers. An example of state participating in this Trust Fund Scheme is the Jigawa State Government Trust Fund for Agricultural Development. The government has pledged some amount of money to assist its farmers take loan for the production of cotton and sugarcane. These farmers now provide raw material for the state-owned sugar factory and cotton ginnery. Other states like Ebonyi, Kogi Plateau and Ondo have also introduced this fund that others should emulate. 
In summary therefore, one can say that despite problems involved in agricultural financing by banks (Deposit money), there are still some options available to facilitate agricultural financing. Among these options are making the agricultural sector profitable, consistency in formulation and implementation of government policies, lowering the costs of capital, formation of agricultural cooperative societies and reduction of loan defaults.

\section{Recommendations}

Given the above, the following policy recommendations were made:

1. More loan facilities should be extended to the agricultural sector to sustain the increase in food production, given the demographic state of Nigeria.

2. A machinery should be put in place to ensure that the amount of loans disbursed eventually get to targeted farmers and the said loan, fully utilized for the purpose they were meant for.

3. To alleviate the problems encountered by farmers, good access roads should be built to facilitate movement of food and cash crops from one location to another and also facilitate harvests. This will have a resultant effect of making agriculture profitable.

4. Land acquisition process must be simplified so as to enable more and more people access to farmland without going through legal hassles.

5. Funds must be made available to serious minded farmers at affordable interest rates.

6. Cash and food crops to be cultivated must be fully identified according to geographical locations where they thrive most. A private consultancy firm should be commissioned by the government to do this.

7. The construction of storage facilities is very vital to the attainment of food sufficiency.

8. More incentives must be put in place to make agriculture more attractive to a large proportion of the nation's working population than the usual white colar jobs.

\section{References}

Ajakaiye, N. (1993). 100 Years of Banking in Nigeria. Potomac Ltd, Owerri.

Aron et al. (1973). The Role of Agricultural Credit, Ibadan University. Ibadan Press.

Asabia. (1990). The Role of Credit in Agricultural Development. London Macmillan Press Ltd.

Bango, D. T. (2001). Challenges of Agricultural Lending. CBN Economic and Financial Review, 32.

Bauman, J. (1996). Agricultural Credit to Primary Producers. Bharmos Ventures Nigeria Limited, Port Harcourt.

Belshaw, M. (1978). The Use of Agricultural Credit to Promote Economic Development. Journal of Nigeria Institute of Bankers, 8(3).

CBN. (2003). Refinancing Scheme for Medium Agricultural Projects, 19, No Nil P. 2 November.

CBN. (2005). Features of Agricultural Credit Guarantee Scheme Fund. CBN News Letter, 2, No Nil.

Central Bank of Nigeria. (1985). Credit Guideline on Sectoral Allocation. CBN Monthly Report, 6, P. 12.

Chidebelu, C. (2004). External Contraints of Agriculture in Nigeria.

Eko, J. N. (2015). Agricultural Loans and the Banks. Universal Resource Location.

Lemo, C. (2005). Realizing Agricultural Full Potential Through Adequate Funding. Wema Bank Plc Annual Report and Statement of Account, 30-35.

Miller, C. (2005). Finance for the Rural Poor. Magazine Home Spotlight Archive, 5(11).

Obansa, S.A.J., \& Maduekwe, I. M. (2013). Agriculture Financing and Economic Growth in Nigeria. European Scientific Journal, 9(1).

Odu, P. C. (2007). Problems and Prospects in Agricultural Financing in Nigeria under Economic Deregulation. $C B N$ Bulletin, 20(3).

Ogwuma, P. A. (1985). The Role of Banks in Agricultural financing. Bullion Publication of CBN, Oct/Dec., pp. 7-9.

Philip, D., Nkonya, E., Pender, J., \& O. A. Oni. (2009). Constraints to Increasing Agricultural Productivity in Nigeria: A Review. Nigeria Strategy Support Programme (NSSP), (6). 